\title{
The historical taxonomy of the Lower Cretaceous theropods (Dinosauria) Calamospondylus and Aristosuchus from the Isle of Wight
}

\author{
Darren Naish
}

\begin{abstract}
NAISH, D. 2002. The historical taxonomy of the Lower Cretaceous theropods (Dinosauria) Calamospondylus and Aristosuchus from the Isle of Wight. Proceedings of the Geologists' Association, 113, 153-163. The historical taxonomy of the small theropod dinosaurs from the Wealden Group (Lower Cretaceous) of England is confused and complex. Of the twelve species names, several are synonymous and the remainder are mostly nomina dubia. Among the latter are the probable bird Wyleyia valdensis, the probable oviraptorosaur Thecocoelurus daviesi and the enigmatic forms Ornithodesmus cluniculus and Calamosaurus foxii. It has traditionally been thought that Calamospondylus oweni, the first British small theropod (or supposed theropod), was renamed and redescribed as Poekilopleuron pusillus, a taxon later given its own genus, Aristosuchus. Fox's correspondence with Owen, and discrepancies in the descriptions of these specimens, show that $C$. oweni and A. pusillus were based on different specimens. A. pusillus is based on a sacrum and partial pubes from a compsognathid coelurosaur. The whereabouts of the type specimen for $C$. oweni is presently unknown.
\end{abstract}

School of Earth and Environmental Sciences, University of Portsmouth, Burnaby Road, Portsmouth P01 3QL, UK

\section{INTRODUCTION}

The Wealden Group strata (Berriasian-Aptian, Lower Cretaceous (Kerth \& Hailwood, 1988; Allen \& Wimbledon, 1991)) of mainland England and the Isle of Wight (Figs 1,2) are famous for their diverse dinosaur fauna (Martill \& Naish, 2001). Because isolated skeletal elements are common in the Wealden Group, and because some nineteenth century workers

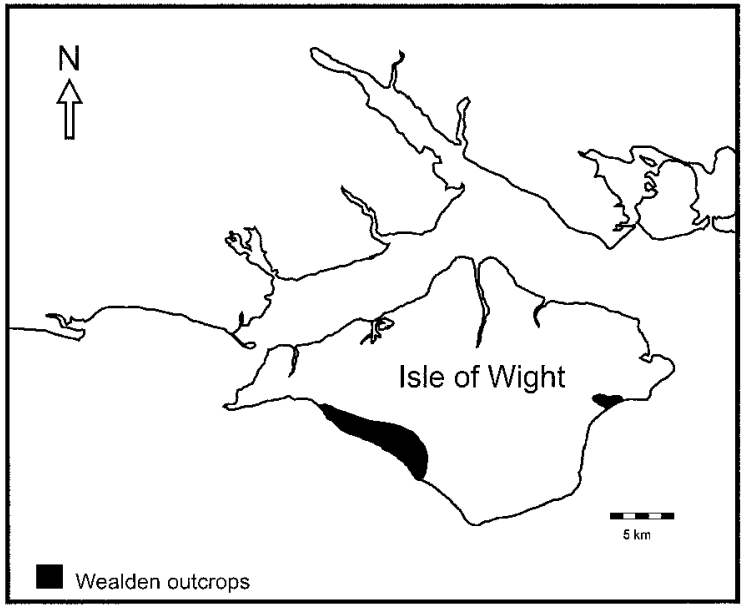

Fig. 1. Sketch map of the Isle of Wight showing the distribution of dinosaur-bearing Lower Cretaceous strata on the island. Calamospondylus and Aristosuchus were both probably collected from the southwest side of the island. used them to erect new taxa, the taxonomy of Wealden Group dinosaurs is complex.

The first supposed Wealden Group theropod material was first mentioned by Buckland (1824) and

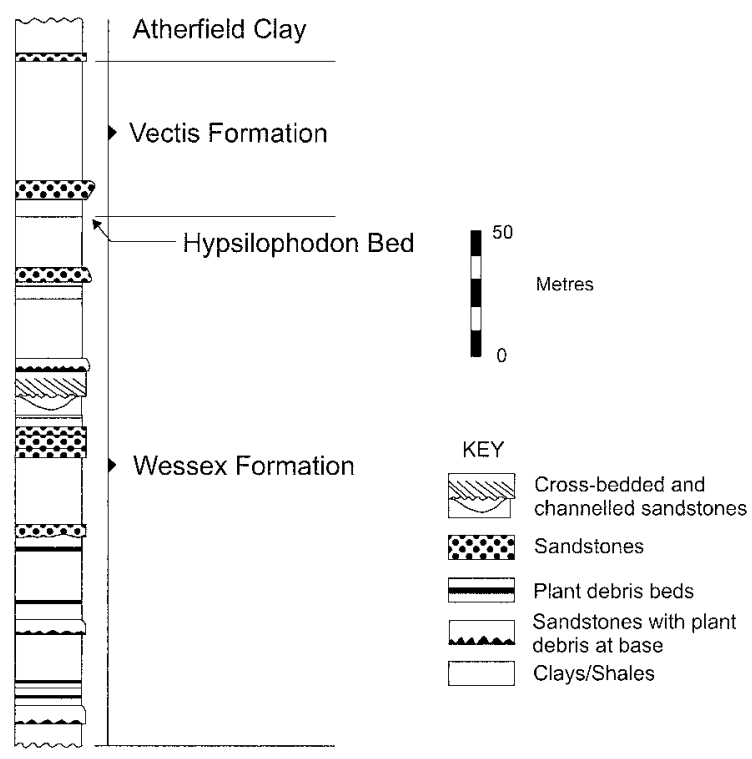

Fig. 2. Simplified stratigraphic log for the Lower Cretaceous Wealden Group of the Isle of Wight. Both Calamospondylus and Aristosuchus were probably collected from the Wessex Formation, though from which horizon is unknown. 
described by Mantell (1846). This consisted of fragmentary elements from Tilgate Forest, Sussex, and was regarded by Mantell as avian. It belongs to pterosaurs, however (Wellnhofer, 1991). Though material that belonged to a large Wealden Group theropod was mentioned as early as 1822 by Gideon Mantell (see Cadbury, 2000), recognition of the first Wealden Group large theropod is usually given to Richard Owen $(1855,1857)$. The first small Wealden Group theropod was not noted until 1866 when the Reverend William Fox briefly described the sacral region of a small dinosaur, assumed by all later writers to be from a theropod, from the Wessex Formation of Brook, Isle of Wight (Fox in Anon., 1866a). Following this report, numerous discoveries were made of small Wealden theropods. In order of publication these are: Calamospondylus oweni Fox in Anon., 1866a; Poekilopleuron pusillus Owen, 1876; Thecospondylus horneri Seeley, 1882; Aristosuchus pusillus (Owen, 1876); Ornithodesmus cluniculus Seeley, 1887a; Thecospondylus daviesi Seeley, 1888; Coelurus daviesi (Seeley, 1888); Calamospondylus foxii Lydekker, 1889; Calamosaurus foxii (Lydekker, 1889); Thecocoelurus daviesi (Seeley, 1888); Wyleyia valdensis Harrison \& Walker, 1973; and Aristosuchus oweni (Fox in Anon., 1866a).

The taxonomy and identity of these taxa have formed part of a larger study on Wealden Group theropods (Naish, 1999a; Naish et al., 2001). Although some of these names may pertain to a single taxon, comparisons of overlapping elements, including sacra, femora and tibiae do indicate that several small-bodied theropods were present in the Wealden Group (Naish, 1999a, b, 2000a). Although often of doubtful taxonomic validity, some of the taxa possess characterstates that allow them to be allocated to specific clades. Thecocoelurus daviesi (Seeley, 1888), named for a partial cervical vertebra (BMNH R181), is probably an oviraptorosaur (Naish \& Martill, 2002). Wyleyia valdensis Harrison \& Walker, 1973, represented only by a small right humerus (BMNH A3658), was originally described as Aves incertae sedis (Harrison \& Walker, 1973) but was regarded as a possible nonavian theropod by Feduccia (1980) and Norman (1990). Zhou et al. (1992) and Feduccia (1996) regarded Wyleyia as avian while Harrison (1991) regarded Wyleyia as an enantiornithine and Kurochkin (1995) suggested it was a palaeognath. BMNH A3658 possesses a number of characters including a proximal ligamental furrow and distal notch for the brachialis anticus which indicate that it is avian. The presence of the fossa for the brachialis anticus indicates that Wyleyia is not an enantiornithine. Howse \& Milner (1993) showed that Ornithodesmus cluniculus Seeley, 1887a, long regarded as the type species for a pterodactyloid pterosaur genus, is a theropod. The affinities of $O$. cluniculus remain controversial and it has recently been compared both with basal theropods (Naish, 1999a, 2000a) and dromaeosaurids (Norell \& Makovicky, 1997). The new large, long-legged coelurosaur Eotyrannus lengi was regarded as a possible basal tyrannosauroid by Hutt et al. (2001). E. lengi is not demonstrably referable to any of the previously named Wealden Group forms (Hutt et al., 2001).

The systematics of the smaller Wealden theropods have been reviewed by a number of authors including Swinton (1936), Ostrom (1970) and Norman (1990). All of these reviews have proposed various synonymies. Ostrom (1970), Norman (1990) and Blows (1998) advocated the referral of most small Wealden Group theropod taxa to the supposed earliest recognized and best known taxon, that represented by the sacrum and pubes BMNH R178, a specimen they believed to represent the type for Calamospondylus oweni. This parsimonious approach assumes a low diversity of small theropods in the Wealden Group. Norman (1985) stated that the names Aristosuchus, Calamosaurus, Calamospondylus, Thecocoelurus and Thecospondylus all pertain to the same taxon, for which he used the name Aristosuchus (but see Norman (1990)).

Because more than one small theropod taxon is clearly present in the Wealden Group (Naish, 1999a, b, 2000a), isolated elements cannot be confidently referred to any one taxon in particular and most or all suggested synonymies cannot be proven. It is therefore unsafe to refer non-overlapping material to Calamospondylus oweni or Aristosuchus pusillus.

Institutional abbreviations: $\mathrm{BMNH}$, Natural History Museum, London; MTCO, Muzeul Tarii Crisurilor, Oradea, Romania; SMNK, Staatliches Museum für Naturkunde Karlsruhe, Germany.

\section{THE CALAMOSPONDYLUS PROBLEM}

Calamospondylus oweni, a small dinosaur based on 'the bones of the sacrum, consisting of five cemented vertebrae with the sacral ribs and portions of the other iliac bones' (Fox in Anon., 1866a), represents the earliest named small theropod from the Wealden Group. Its nomenclatural history is convoluted: it has been universally confused with Aristosuchus pusillus (Owen, 1876) and has also been considered congeneric with Calamospondylus foxii Lydekker, 1889. Validity of the name $C$. oweni has been problematic due to the place of publication and the inadequacy of the original description. These problems have been compounded by the assumption that the name $C$. oweni was created for the theropod specimen BMNH R178 (Fig. 3): however, this is not the case (see below).

C. oweni was discovered by the Reverend William Fox at Brook, Isle of Wight (Fox in Anon., 1866a; Blows, 1983). This is proven by one of Fox's letters to Owen (believed to date from 1866 (Blows, 1983)) in which Fox alluded to the creation of a generic name that would be the (roughly) translated version of 'reed-like vertebrae' (Fox in Blows, 1983). This name was first published in The Athenaeum of June 2, 1866 


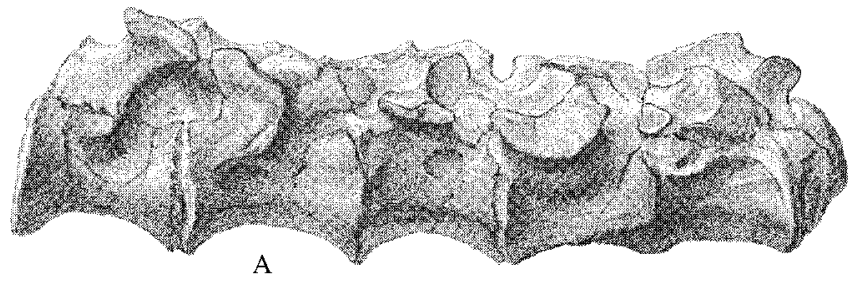

A
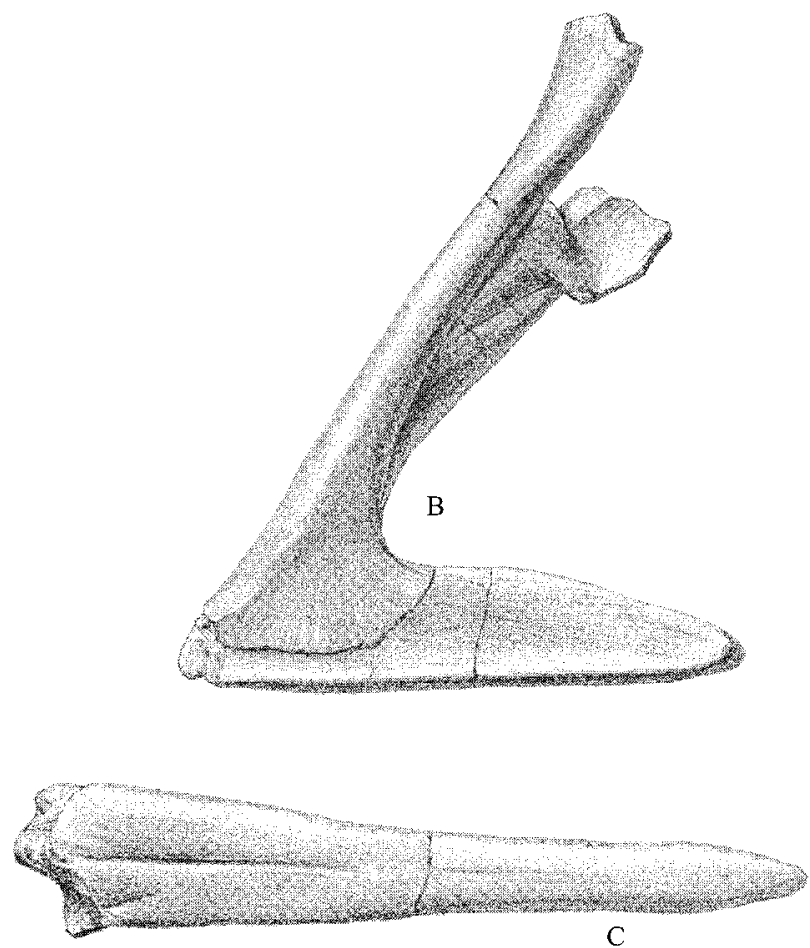

Fig. 3. BMNH R178 as figured in Owen's (1876) plate. This specimen was designated by him the type of Poekilopleuron pusillus. (A) left lateral view of the sacrum; (B) left lateral view of the pubis; (C) ventral view of the pubic boot.

(Fig. 4). Despite the informal place of publication, briefness of description and extreme difficulty that arises when one tries to determine which specimen Fox (in Anon., 1866a) was writing about, Calamospondylus oweni satisfies the requirements of Article 12 of the International Commission on Zoological Nomenclature (ICZN, 1999). Article 12 (names published before 1931) states that names must meet the requirements of Article 11 and must (if not accompanied by an indication, see Article 12.2) 'be accompanied by a description or a definition of the taxon that it denotes' (p. 16). C. oweni is therefore accepted here as a properly published name and is not regarded as a nomen nudum (as it is in Naish et al., 2001). Fox's announcement on $C$. oweni was included within a larger section of text and there are several indications that none of this was written by Fox himself. Firstly, the article refers to Fox as its subject and does not read as if he wrote it. It is also not signed by Fox but is included within a larger section of anonymously credited text. This text was probably written by an Athenaeum editor and is here cited as Fox in Anon. (1866a).

Fox's (in Anon., 1866a) Athenaeum article was reproduced in The Geological Magazine. That two identical articles appeared in 1866, both including the name C. oweni, has resulted in some difference of opinion with regard to which should be cited as the first publication of $C$. oweni. Lydekker (1891), Ostrom (1970) and Benton \& Spencer (1995) all cited The Geological Magazine and did not cite The Athenaeum article. Norman (1990) and Insole \& Hutt (1994) cited The Athenaeum reference. Swinton (1936) listed both articles in his bibliography, but only referred to The Athenaeum. The Athenaeum was a semi-popular magazine and seems an inappropriate place of publication for an article in which a formal taxonomic name was erected. This may explain why it was 


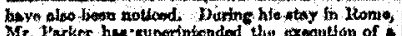

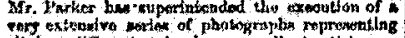

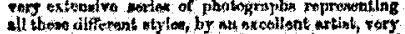

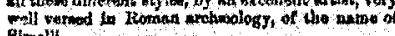
Bimolli

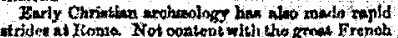

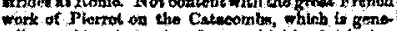
ralls considiond to give far too highily finimhorl a

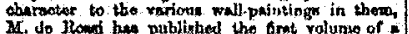

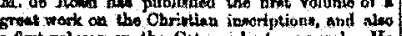

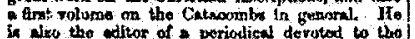

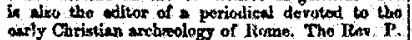
Garly Christian axchnology of Itcane. The Ther. P. Garcural hin proparod a third odition of hin rothe comis; whilat the For. Abbo Binthior do Mont

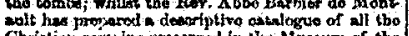
Christiun rowning precored in the Bt usoum of the Yatican Liltary (whares by the by, wo lately mat Prod. Tinetiandor, bavily ang

It mer bo anefat to wome of your readen to bo biformol that many of tho objucts which wers in the Mfnuepto of the Vatican hire boen remorol to Ei Jobn Lateran, whicin will in timo becotec the great Christian Museum of Rome. Hare, for incophas, an pell an tho Chriating inscriptione (oxcopt theso in the long gellery of the Vations lewlinf to

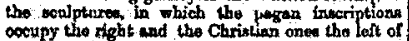
the gullery. The colloction of theno inseriptions tho gullery. The collection of theno inscriptions at St John Lateran bas boen earefully arranged,

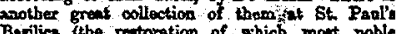
chanch would of itelf be sulfient to mart the reign of my eropeign pontifi); these arv now Gred in the palleries leading to the librart. A ofromo-lithographic wart an the 'Christian Moseles of Rome is in progress, the trat numbar of which
the bo ready for problication, by Spitbover, sbout
the of the fruent year.

The excanntions at San Clomento wo being oomthood under tho direction of the excellent Pdor, bexiliex, which is owe of the oldest in Rame, and well bown for its loterosting moinaics and it two manble nombenes: in there original pocition, is

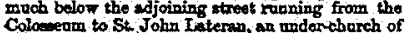
Iargo size tha been discorered, with nomerous very onry mill-paintingt and fino marble colluwins. The the high ilsur of the uppor ohurch, which, it is foarod, will bs po to be thren down and rebuilt. And, till deeper, s hoose ha been discovered, Which to doobtecen the precareor of tho lower tell io number. The axcarstion undertiken by Mr. Parker,
with the cansent of the Abbens of St. Pudentians, Geometh the considing church (which, lite Sis trewt), bive been stopped by order of the saperiox anthoritien. Soticiemt has, bowover, been found to show that a prooiding bectios axtended bonsesth

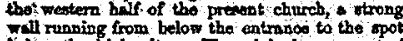
tolow the high , itter. The original paremant of

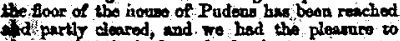

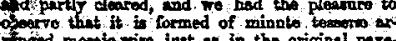
7.

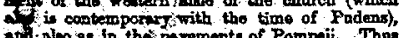
ati aro browght into the residenos of the Tho cetaror Podens.

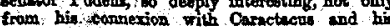
Jromily, trut alno from the faot to which Podeses was the : Bowes, and that, the bitosalf bis, on neveral poos ions, boen it inimate The nltar in this moot

in tonill on

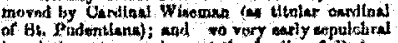

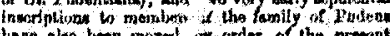

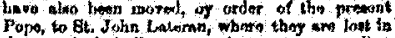

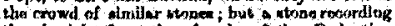
the barid af anothos famalo of tho Pudentian

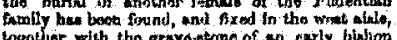

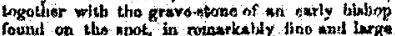

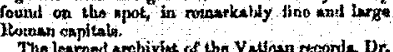

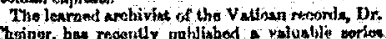

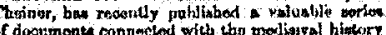
of rooumonth conyortad with tho troliatsal histury, hngland awd toostistad trom orginale ondor his

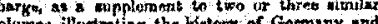
ther eountrie of Etropa J O. W ode whekLY Gowir.

Tan Queve has oorrectod the jopular idos that the socond ond of the Britieb Sijveroign must atred Daks of Edinburgb. Thin titto ham never hefore treen conferred on the won of a roigniog ovorciga Is bas bsen enjoyed by Frodtariek, non Socond), by Frederick' son; George (evitsonquently George the Third), by Prince Willism, Goorga tha Third' brother, os Iuke of Gloucenter nad Edin. beargh, and lashly, by Prince. Willian'w non, Whiliam Frodarick, who died cbillulow, in 1834 . The Duke of York in a far older and nobler tille.

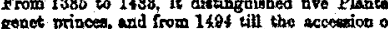
Janes the Second, it was the title of the econd wons of Henry the Sorrenth, Jamea the Kints and Carilos the First; all of whom became Kings of England. An Dakes of Fork and Allunys, hare hud, from 1716 to 1827 , Errout, the brothor of George the Firs; ; Edwand, trother of George the Thin; and Frederick, wocoud son of George t The Profossons of Jnivenity College will hold their ovening rexeptions on Friday, the seh of Jane, in Gotrer Street. This Year the learned body wro trying the plenten

Cardo have been lanved for tho Society of Arte Convergacione for Wednendisy, the 13th of June Tho Souts Ketaington Musturn.

Thoos of our reader wino teko an ipterent in our early history will, no doubt, bo gratified by the information that Mr. Thorpe is prepariog an odi. tion of the Topographical Churters of Englend,
dating from tho reign of King Ftbollerbi, A.D. 601, to the Normen Corqued. In this work the docawents will be classod in covntios, beninning to the Domeeday Surrey of that county. As in the 'Diplomatarium Anglisom' fof which this is and the Isad-Boundarios will be socompanisal by

The fino colloction of Orford worthien, formed

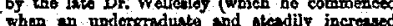

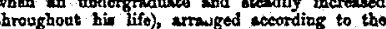
difturent colleges, and conaisting of many bundred engraved portraits, has recontly bees ocquired by the Hope Crrator and added to the Hopesen col. lection of portraita, now deponited in tho Gallary.

The but of Cant. Speke has locon erected at Twantos in the shire.tall, with an inscription from the pen of Sir Helng Rawlinano. Spetie is reconded as "The discoverer of tho monrcen of the catimonial mean that Sir Hesiy disputes the fact of dimoovery, ike so miagy othes geograpbsal

A Correpondent hya: "Your philologist axe gur beit Tho iden of the , wond, as employed by

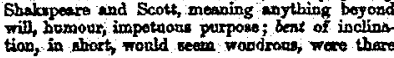

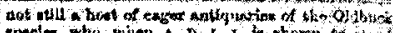

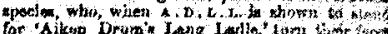

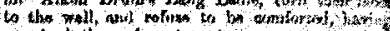

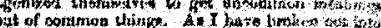

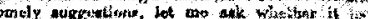

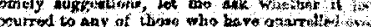

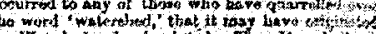

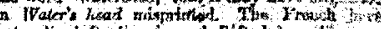

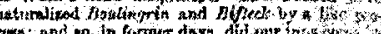

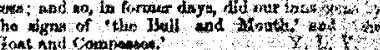

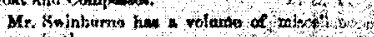

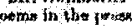

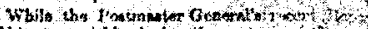

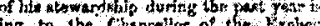
ing to the Chancellor of the Exptris o

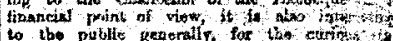
Lo the public geaertily, for the ectrits intical information that it rimescian that

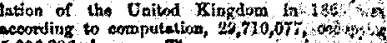

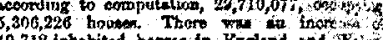
, 712 inhabitad honwen fo Koglesid and w w

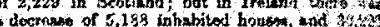

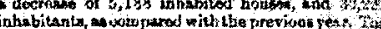

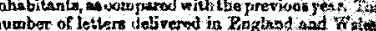

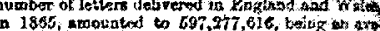

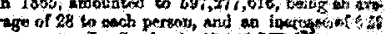

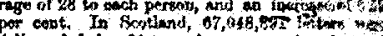
delivered, being 21 to esch persos, sud an thing

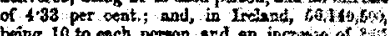
being 10 to mach person, exd an inctare of 9 it

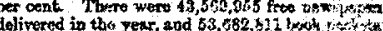

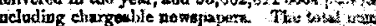

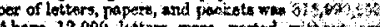

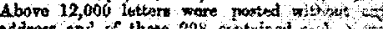

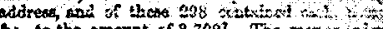
We, to the ynount of 9,7002 . The prosey rish amouniod to $18,140,650$. Thess nits bits

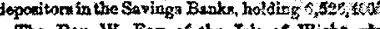
The Rev. W. Fox, of the Twlo of Wights wh last mummer dimoosered hin Polacanthys Parth hat The dincovered parts of this onimal are similat the diecovered parts of thin animal sre timila of the other ilisc bon the aecral ribas and portions are quite saffieient to show thist the reptile which they belonged was of the Dinowarish which they belonged was of the Dinoweurish monoters of the world of etsat, the cecrum seing only nix inches in length; yet part trom its ap it had as mueh of nopelty bout it as some of the previously discovered desgorst. The bones of moro hollow, hight, and oompect in structure then the banes of birds, and quite $a$ mueh so ox there of the ptenodactyls, with foramina for the admiscian of air into them, like the bones of the lowirimmed reptiles. Such a formation was oridertly given for the purpose of leaping from tre to troe o for bounding from the grasp of other reptset with an elwoticify of epring equalling thet of the 13 . hopper. With the approval of Prof. Oxeen, whe has axamined the bones, this net repsile has bet it the decriptivo namo of "c Colno has giren it the descriptive namo of "Colanouspordus hollow, wmooth, and compant like $\alpha$ real

We have reociped a copg of $\mathrm{Ar}$. Collier' refract of 'The Phosnix Nest; a datinty oolleotion of pacto poblinked is 1593, and of angular istertst Collier is doing on axellont sonvice by the mets of then rare tiocen

How moeb longer is the pablic com on toret

to bo outraged, and the healib of Futefastits

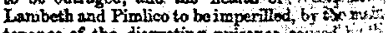

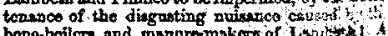

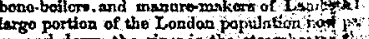
up and down tho rivor in tho eteambronsy th?

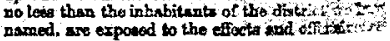

Fig. 4. Reproduction of p. 740 from The Athenaeum, 2014, p. 740 (2 June, 1866). Fox's article on C. oweni is in the bottom half of the third column.

ignored by some authors (e.g. Ostrom, 1970). Swinton (1936) considered Fox's C. oweni of 'no nomenclatural significance' because it was published 'in a "gossip note", and 'without definition' (Swinton, 1936, p. 207). Swinton's (1936) view on Calamospondylus Fox had implications for his opinion on Calamospondylus Lydekker and its replacement name Calamosaurus Lydekker (Naish, 1999a). The Geological
Magazine article was published in part XXVI of volume III: this is dated on its cover as appearing in August 1866. It is therefore preceded in publication by The Athenaeum article and the latter is regarded here as the formal source of the name Calamospondylus oweni.

Some items of historical interest regarding Calamospondylus are evident from Fox's letters to Owen (Blows, 1983). Fox suggested in an 1866 letter that 
Calamospondylus might be awarded a specific name honouring Alfred Lord Tennyson, a friend and associate of Fox, and a man whom Owen also knew personally (Blows, 1983). Fox's eventual decision to name Calamospondylus in honour of Owen was apparently, however, to Owen's approval (Fox in Anon., 1866a). This strongly indicates that Owen's (1876) species Poekilopleuron pusillus, a name assigned without any doubt to the specimen BMNH R178, was not a renaming of $C$. oweni. Fox also appears to have been the first person to suggest that small theropods may have possessed scansorial abilities (Naish, 2000b).

The Geological Magazine article on C. oweni was published in the 'miscellaneous' section of the journal and was not signed off by the initials of an author. Instead, it was credited to 'Athenaeum' - thus it shares its author with the writer of the latter article and is cited here as Anon. (1866b). Here ends Fox's contribution to the taxonomy of the smaller Wealden theropods, and from hereon the subject is complicated by the writings of other authors.

\section{OWEN, SEELEY AND BMNH R178}

Previous authors have assumed that whatever theropod material was described and named by Fox (in Anon., 1866a) was made better known by Owen's apparent redescription of it in 1876 (Owen, 1876). Owen (1876), as is apparent from his description and accompanying plate, described the theropod sacrum and pubes BMNH R178 (Fig. 3). He regarded this as crocodilian, referring it to Poekilopleuron, a genus erected for $P$. bucklandii from the Bathonian of France (Eudes-Deslongchamps, 1838). This species is a large, Megalosaurus-like theropod (Paul, 1988; Molnar, 1992). Owen did not approve of EudesDeslongchamps' spelling of Poekilopleuron and insisted on spelling it Poikilopleuron: Owen had instated this respelling in 1842 for $P$. bucklandii (Owen, 1842 ) and thus did not use it exclusively for $P$. pusillus (which demonstrates that it was not an attempt to erect a new genus). It is one of eight spelling variations of this name (Olshevsky, 1991) and, as it is incorrect, Owen's (1876) name for BMNH R178 should be written Poekilopleuron pusillus.

Owen's (1876) reason for referring BMNH R178 to Poekilopleuron rested entirely on one feature of the vertebral centra - the relatively large cavity within each centrum, referred to by Owen (1876) as the 'central chondrosal vacuity' (Owen, 1876, p. 2). This referral of BMNH R178 to Poekilopleuron was reviewed by Hulke (1879) who established the theropodan nature of $P$. bucklandii, predominantly on the morphology of the distal tibia. Hulke (1879) was confident that $P$. bucklandii was a junior synonym of Megalosaurus bucklandii, an opinion also promulgated by Paul (1988), but Hulke did not provide any taxonomic opinion on P. pusillus.

Owen (1876) noted that the material he named $P$. pusillus comprised eight vertebrae, an ungual phalanx and a pair of fused distal pubes. He did not recognize the true nature of the latter and suggested that they might represent part of the series of abdominal ribs and a sternum (Owen, 1876, p. 2). This identification was not original, as Fox had previously suggested a similar identification in one of his letters. In Owen's (1876) plate, the pubic foot of BMNH R178 was labelled a haemal spine, and the shafts of the pubes were labelled as haemapophyses. BMNH R178 is not described in detail here as it has previously been described by Owen (1876) and Huene (1923, 1926a,b). The osteology, systematics and phylogenetic affinities of this specimen form part of a larger study in progress on Lower Cretaceous coelurosaurs and are not discussed here. As noted in Naish (1999c), BMNH R178 is probably a compsognathid and is very similar to Compsognathus.

Nowhere in Owen's (1876) text did he formally state that he had created a new taxon for the reception of this material, although it is evident from the name 'Poikilopleuron pusillus, Ow.' heading the respective section that he did so.

\section{Removing BMNH R178 from Poekilopleuron}

Seeley $(1887 b, c)$ took issue with Owen's (1876) assignment of $P$. pusillus and, recognizing that BMNH R178 did not represent a crocodile but a dinosaur, drew attention to Marsh's (1884a, b) identification of BMNH R178 as a theropod (see below) (Seeley, 1887b). In fact, Seeley (1887b) noted (as did Lydekker, 1888) that Marsh (1884a, b) had even referred BMNH R178 to Coelurus (see below). Seeley $(1887 b, c)$ also argued that the presence of Owen's chondrosal vacuities (Seeley's medullary cavities) in the vertebrae of BMNH R178 did not provide a satisfactory morphological basis on which to assert a genus-level relationship, as per Owen (1876), for Seeley (1887b, c) was aware that such cavities were widely distributed in dinosaurs. This meant that there was no basis for Owen's (1876) referral of BMNH R178 to Poekilopleuron. Consequently, Seeley (1887b) gave the specimen the new generic name Aristosuchus.

Seeley (1887b) correctly identified the pubes of BMNH R178 and suggested that the ungual phalanx BMNH R179, regarded and illustrated by Owen (1876) as part of the $P$. pusillus material, did not belong together with it, but was in fact from a pterosaur. This does not appear to be correct, and the phalanx is here regarded as theropodan. Lydekker (1888) argued that, on the basis of its strong similarity to the third manual ungual of Allosaurus, BMNH R179 most probably belonged to the same animal as BMNH R178 (see Appendix).

The non-sacral vertebrae that have also been considered to belong to the same individual as BMNH R178 (the dorsal vertebra BMNH R178a and the two caudals both labelled BMNH R178b) cannot definitely be associated with it. Jurcsák (1982) and Jurcsák \& Popa (1983) even referred material from the Lower 
A
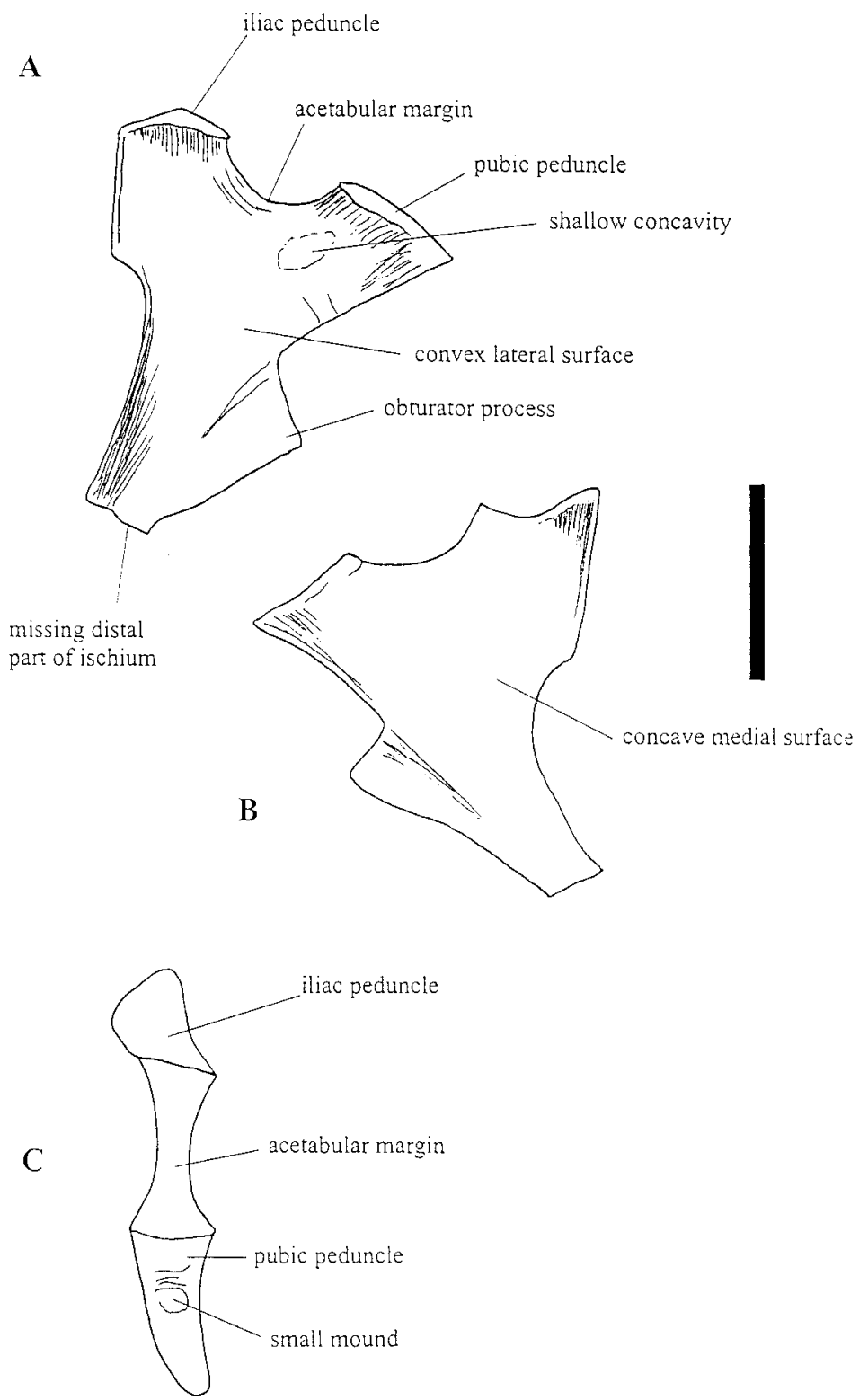

Fig. 5. BMNH R6426, a small (probable right) incomplete ischium that has been referred to A. pusillus, in (A) lateral, (B) medial and (C) dorsal view. Scale bar $20 \mathrm{~mm}$.

Cretaceous of Cornet, Romania, to Aristosuchus as the undetermined taxon Aristosuchus sp. Benton et al. (1997) noted that, if correct, this referral would require that the Romanian theropod be somewhat larger than that represented by BMNH R178. Given that the supposed Romanian Aristosuchus material consists only of two isolated vertebrae (the cervical MTCO 16499 and the incomplete caudal MTCO 17245), Jurcsák (1982) and Jurcsák \& Popa’s (1983) referral must be considered extremely dubious.
In discussing the theropodan nature of Aristosuchus, Seeley (1887c, p. 223) wrote that Henry Woodward 'submitted to me the pubis, imperfect distally, of a type very similar to Coelurus, from Tilgate'. The undescribed partial ischium BMNH R6426 (Fig. 5) may also be referable to Aristosuchus. This could be correct but cannot be confirmed; the proximally located triangular obturator process shows that the specimen is from a coelurosaur (Holtz, 2000) and in general shape it resembles the ischia of 
compsognathids. Unfortunately, it cannot be compared directly with the type specimen of Aristosuchus.

\section{ARGUMENTS OVER SENIORITY: CALAMOSPONDYLUS OR ARISTOSUCHUS?}

Because it has been widely assumed that the specimen named $C$. oweni by Fox (in Anon., 1866a) was the same as that later called $P$. pusillus by Owen (1876) and then A. pusillus by Seeley $(1887 \mathrm{~b}, \mathrm{c})$, it has been argued that both names should be regarded as junior synonyms of C. oweni (Norman, 1990; Weishampel, 1990; Insole \& Hutt, 1994; Blows, 1998; Kirkland et al., 1998). However, a number of other authors have regarded $A$. pusillus as the 'best' available name for BMNH R178 (Swinton, 1936; Steel, 1970; Galton, 1973; Madsen, 1974; Blows, 1983; Norman, 1985; Paul, 1988; Olshevsky, 1991). In these latter cases, the indication has always been that these authors regarded C. oweni as a nomen nudum created for BMNH R178, and not that they regarded it as pertaining to a different specimen.

Paul (1988) provided an exception to those that have accepted Aristosuchus as valid in that he acknowledged Fox's specific name by creating the new combination Aristosuchus oweni. This clearly assumes that both names refer to the same specimen but because Paul's (1988) use of the specific 'oweni' indicates that he regarded Fox's name as valid (and not a nomen nudum), he should have used the generic name Calamospondylus in preference.

\section{Was Poekilopleuron pusillus a renaming of Calamospondylus oweni?}

That Fox (in Anon., 1866a) created the name C. oweni to honour Owen makes it seem unlikely that, shortly afterwards, Owen would simply disregard this name in favour of a new one created by himself. Furthermore, that Owen (1876) ignored the name $C$. oweni, making no mention of it in his 1876 description, nor making any mention of Fox's (in Anon., 1866a, b) articles, strongly suggests that he thought he was dealing with a different specimen. This supposition is supported by a number of facts that have been overlooked by previous authors who have regarded $P$. pusillus and $C$. oweni as synonymous.

Firstly, when Fox (in Anon., 1866a) wrote about the sacrum 'and portions of the iliac bones' named by him C. oweni, these remains were considered to be from a dinosaur (Fox in Anon., 1866a). This identification was confirmed by Owen (Fox in Blows, 1983). It seems strange then that, if the C. oweni material is the same as BMNH R178, Owen (1876) should later consider this to be crocodilian. The possibility exists that (supposing that $C$. oweni and $P$. pusillus do represent different names for the same specimen) Owen changed his mind with regards to the dinosaurian nature of the Calamospondylus material. This argument is, therefore, inconclusive.
Secondly, the respective sizes reported for C. oweni by Fox (in Anon., 1866a, b) and the size of BMNH R178 are significantly different. Fox (in Anon., 1866a) describes the $C$. oweni sacrum as six inches long (152.4 mm). Owen (1876) did not report measurements of BMNH R178. However, there is no doubt that this is the specimen he was describing and its total length is $125 \mathrm{~mm}$. A difference of $27.4 \mathrm{~mm}$ therefore exists between Fox's (in Anon., 1866a) measurement of the C. oweni sacrum and the sacrum of BMNH R178. A $27.4 \mathrm{~mm}$ discrepancy is high for specimens only measuring around $125 \mathrm{~mm}$ in total length. This suggests that Fox (in Anon., 1866a) was not writing about BMNH R178.

What appears likely, and yet has been overlooked by all authors who have reviewed Wealden theropod taxonomy, is that Fox actually discovered two dinosaur specimens, both of which consisted predominantly of a sacrum, both of which were discovered around, or within, 1866, and both of which formed the basis of correspondence between Fox and Owen. In his biographical review of the Reverend Fox, Blows (1983) reproduces two 1866 letters sent by Fox to Owen, both discussing the discovery of small dinosaur material. In the first letter, stated by Blows (1983) to date to March 2, 1866, Fox wrote:

If you feel, as I do, that the light sacrum in your hands as well as the larger vertebrae, belong to reptiles as yet unrecognised and you think you have in the specimens sufficient data on which to establish new specific character, may I ask you as our great Palaeontological High Priest to give them names. What say you to the little one being named -spondylus [sic] from its reed [italics in original] like backbone. Add if you like your own name as a specific one. Call the other what you think proper; but do you think that your friend Tennyson, who without being deeply learned on these matters, can sing so beautifully of this saying 'A monstrous eft was of old etc' and who smoked like a true Philosopher over the grave of the old Eft while I was digging up some fragments of his bones, do you think I say that he would like to have his name linked with this dragon? If you deem the suggestion illjudged [sic] let it die in the flames with this paper... (Fox in Blows, 1983).

The problem with Fox's letter here is determining which theropod specimen(s) he was specifically referring to. While it is abundantly clear that Fox was writing about the specimen that he subsequently named C. oweni, was he writing, as Blows (1983) assumed, about BMNH R178? I do not believe he was, because in the second 1866 letter, reproduced below, Fox clearly writes about a second small dinosaur sacrum, and makes a number of references which strongly indicate that here he was referring to $\mathrm{BMNH}$ R178. 


\section{Fox wrote:}

I found a few small bones the other day and they strike me as being rather interesting and I have a good opportunity of sending them to you by a friend, I have no doubt you will be happy to have the opportunity of inspecting them.

The whole were found in the compass of a dinner plate and in a bed were [sic] bones are not usually huddled together so that you may rely on their belonging to the same reptile. I suppose the two long bones are clavicles and if so, I judged it would be interesting to you to meet with them attached as they are to a breast bone. You will see in the small vertebrae which is in two pieces that it has been hollow. If you wish to examine the sacrum more narrowly then you can seeing [sic] I have cemented the pieces together, I daresay you would find the cement easily give way if you had a rag steeped in naptha $[\mathrm{sic}]$ put round the fractures for a short time. The fracture near the breast bone will reveal the internal structure most clearly. But I think you will find no cavity except for the spinal cord which is very large indeed for such a small vertebra. The sacrum is I think quite different from the one in your possession of 'Calamospondylus Oweni' and yet perhaps not so far different but that the accompanying additional bones of the one may serve to assist in interpreting the other. I hardly like to express my crude thoughts lest I should say something unusually silly, yet I shall be rather anxious to hear whether you see any indication of a wing in the bones submitted to you (Fox in Blows, 1983).

Given that, in this letter, Fox refers to two long bones that he tentatively regarded as clavicles as well as a common element to which both were joined, it seems clear that the specimen he was describing was BMNH R178. Surely it cannot be coincidental that Owen (1876) regarded the distally fused pubes of BMNH R178 as representing abdominal ribs fused to a sternum. It is therefore particularly important that Fox explicitly states that BMNH R178 is "quite different from the one in your possession ... of "Calamospondylus Oweni", Whichever specimen the name C. oweni was based on, it was therefore not the same as BMNH R178. C. oweni, therefore, is not a senior objective synonym of $P$. pusillus and A. pusillus, and $A$. pusillus is, after all, the correct name for BMNH R178. Unfortunately, the fossil described by Fox (in Anon., 1866a, b), and named $C$. oweni by him, is lost.

\section{The validity, or otherwise, of Calamospondylus oweni}

While $C$. oweni satisfies Article 12 of the ICZN, it is regarded as a nomen dubium because none of the characters described by Fox (in Anon., 1866a, b) are unique to this species. The fact that the type specimen is lost is irrelevant with regard to this issue (ICZN,
1999). Fox (in Anon., 1866a) mentions four features that might have been used to distinguish $C$. oweni from other dinosaurs (see Fig. 4); the presence of five cemented vertebrae; its small size; bones which are more hollow in structure than those of birds; and the presence of foramina on at least some of the bones. None of the features is unique to $C$. oweni.

Among dinosaurs, the presence of five sacral vertebrae is widespread and ubiquitous among Theropoda (Holtz, 2000). Several non-avian theropods are now known whose conjoined sacral vertebrae measure less than 152 mm (e.g. Ostrom, 1978; Xu et al., 1999, 2000; Burnham et al., 2000), so small size is not unique to $C$. oweni. Indeed, comparison with other theropods suggests that a specimen with a sacrum $152 \mathrm{~mm}$ long may have been around $2.5 \mathrm{~m}$ in total length (Naish et al., 2001) and thus not 'small' when compared with truly diminutive non-avian theropods (the eumaniraptoran Microraptor, for example, may have been less than $400 \mathrm{~mm}$ in total length (Xu et al., 2000)). Extremely thin-walled, hollow bones are also not unique to $C$. oweni. In the coelurosaur SMNK 2349 PAL, for example, the wall of the femur is only about $1 \mathrm{~mm}$ thick (Martill et al., 2000). Fox's fourth feature, the presence of foramina on some of the bones of C. oweni, is too vague to permit detailed assessment: was he referring to foramina on the sacral vertebrae or on the pelvic elements? However, neither would be unique to C. oweni. Foramina on the sacral vertebrae have been reported in dromaeosaurids and other theropod taxa (Norell \& Makovicky, 1997), among which are the Isle of Wight theropods Eotyrannus lengi and Ornithodesmus cluniculus (Hutt et al., 2001). This raises the intriguing (but untestable) possibility that $C$. oweni is synonymous with either of these taxa. Foramina on pelvic elements are also seen elsewhere in the Theropoda (e.g. Foster \& Chure, 2000) and thus would not be unique to $C$. oweni. Unfortunately therefore, Fox's description of $C$. oweni does not provide any features that might support recognition of this species as distinct.

\section{CONCLUSIONS}

The convoluted history of $C$. oweni, $P$. pusillus and $A$. pusillus can be summarized as follows:

1. In, or slightly before, 1866, Fox discovered a small dinosaurian sacrum, accompanied by some other remains from the pelvic region, at Brook, Isle of Wight. He informed Owen of this discovery and suggested that a new taxon might be created and that it might be; (1) given a generic name based on the root word 'spondylus'; (2) named in allusion to its thin-walled, hollow construction (which reminded him of a dried reed); and (3) given a specific name in honour of Owen himself. Without any doubt, this specimen is the same as that given the name Calamospondylus oweni by Fox in 1866. 
2. Fox named this new taxon in The Athenaeum of June 2, 1866 (Fox in Anon., 1866a). This article was reproduced in The Geological Magazine of the same year (Fox in Anon., 1866b). This description fulfills the requirements of the ICZN (1999) and thus Calamospondylus oweni is regarded as a properly published name. However, the lack of any diagnostic features in the lost type specimen mean it must be considered a nomen dubium.

3. At about the same time, Fox discovered a second specimen on the Isle of Wight (the exact location is unknown) comprising a sacrum with two elongate elements joined to a single median element. This specimen is BMNH R178 and Fox made it clear in his correspondence to Owen that it was different from the holotype of Calamospondylus oweni. Owen (1876) described and named BMNH R178 as a new species of Poekilopleuron; Poekilopleuron pusillus.

4. Seeley $(1887 b, c)$ recognized that BMNH R178 was not referable to Poekilopleuron and created the new genus Aristosuchus. BMNH R178 thus became Aristosuchus pusillus (Owen, 1876).

5. Subsequently, several authors assumed that Fox's Calamospondylus oweni was a reference to the same specimen as BMNH R178 and therefore regarded C. oweni as the oldest name given to this specimen. As explained above, the name $C$. oweni was not created for BMNH R178 and Aristosuchus pusillus is the correct name for this specimen.

\section{ACKNOWLEDGEMENTS}

I thank David Martill for discussion and assistance during research. William Blows, Michael J. Benton,
David Loydell, Nick Longrich and Oliver Rauhut provided useful comments and discussion. Two anonymous reviewers provided useful comments that improved the manuscript. Sandra Chapman and Angela Milner allowed access to specimens. John Moore obtained The Athenaeum article. Stig Walsh provided assistance with the figures.

\section{APPENDIX}

\section{Discussion of the Wessex Formation theropod unguals BMNH R179 and R899}

Referral of the ungual BMNH R179 to the animal represented by BMNH R178, and of the similar ungual BMNH R899, cannot be demonstrated. BMNH R179 is missing its dorsoproximal part, meaning that presence or absence of the dorsoproximal depression cannot be confirmed. In BMNH R899 the dorsoproximal region is preserved, showing that the specimen lacked the dorsoproximal depression seen in ornithomimosaurs, tyrannosauroids, oviraptorosaurs, dromaeosaurids and troodontids (Rauhut \& Werner, 1995). In BMNH R899 the flexor tubercle is weak and distally located. The manual unguals of Compsognathus also lack dorsoproximal depressions and have weak, distally located flexor tubercles (Ostrom, 1978;Rauhut \& Werner, 1995), suggesting that BMNH R899 may be a compsognathid ungual. However, similar manual unguals are seen in the oviraptorosaur Caudipteryx (Zhou \& Wang, 2000). In contrast to BMNH R899, BMNH R179 has a much more prominent, proximally located flexor tubercle so may belong to a different theropod taxon.

\section{REFERENCES}

Allen, P. \& Wimbledon, W.A. 1991. Correlation of NW European Purbeck-Wealden (nonmarine Lower Cretaceous) as seen from the English type areas. Cretaceous Research, 12, 511-526.

Anon. 1866a. Another new Wealden reptile. The Athenaeum, 2014, 740 .

Anon. 1866b. Another new Wealden reptile. The Geological Magazine, 3, 383.

Benton, M.J. \& Spencer, P.S. 1995. Fossil Reptiles of Great Britain. Chapman \& Hall, London.

Benton, M.J., Cook, E., Grigorescu, D., Popa, E. \& Tallodi, E. 1997. Dinosaurs and other tetrapods in an Early Cretaceous bauxite-filled fissure, northwestern Romania. Palaeogeography, Palaeoclimatology, Palaeoecology, 130, 275-292.

Blows, W.T. 1983. William Fox (1813-1881), a neglected dinosaur collector of the Isle of Wight. Archives of Natural History, 11, 299-313.

Blows, W.T. 1998. A review of Lower and Middle Cretaceous dinosaurs of England. New Mexico Museum of Natural History and Science Bulletin, 14, 29-38.

Buckland, W. 1824. Notice on the Megalosaurus or great fossil lizard of Stonesfield. Transactions of the Geological Society of London, 2, 1, 390-396.
Burnham, D.A., Derstler, K.L., Currie, P.J., Bakker, R.T., Zhou, Zhonghe \& Ostrom, J.H. 2000. Remarkable new birdlike dinosaur (Theropoda: Maniraptora) from the Upper Cretaceous of Montana. The University of Kansas, Paleontological Contributions, 13, 1-14.

Cadbury, D. 2000. The Dinosaur Hunters. Fourth Estate, London.

Eudes-Deslongchamps, J.A. 1838. Mémoire sur le Poekilopleuron bucklandi, grand saurien fossile, intermédiare entre les crocodiles et les lezards. Mémoires de la Société Linnéenne de Normandie, 6, 37-146.

Feduccia, A. 1980. The Age of Birds. Harvard University Press, Cambridge, Mass.

Feduccia, A. 1996. The Origin and Evolution of Birds. Yale University Press, New Haven and London.

Foster, J.R. \& Chure, D.J. 2000. An ilium of a juvenile Stokesosaurus (Dinosauria, Theropoda) from the Morrison Formation (Upper Jurassic: Kimmeridgian), Meade County, South Dakota. Bringham Young University Geology Studies, 45, 5-10.

Galton, P. 1973. The femur of a small theropod dinosaur from the Lower Cretaceous of England. Journal of Paleontology, 47, 996-1001. 
Harrison, C.J.O. 1991. Fossil birds. In (Brooke, M. \& Birkhead, T.; eds) The Cambridge Encyclopedia of Ornithology. Cambridge University Press, Cambridge, 69-76.

Harrison, C.J.O. \& Walker, C.A. 1973. Wyleyia: a new bird humerus from the Lower Cretaceous of England. Palaeontology, 16, 721-728.

Holtz, T.R. 2000. A new phylogeny of the carnivorous dinosaurs. Gaia, 15, 5-61.

Howse, S.C.B. \& Milner, A.R. 1993. Ornithodesmus a maniraptoran theropod dinosaur from the Lower Cretaceous of the Isle of Wight, England. Palaeontology, 36, 425-437.

Huene, F. von 1923. Carnivorous Saurischia in Europe since the Triassic. Bulletin of the Geological Society of America, 34, 449-458.

Huene, F. von 1926a. On several known and unknown reptiles of the Order Saurischia from England and France. Annals and Magazine of Natural History, Series 9, 17, 473-489.

Huene, F. von 1926b. The carnivorous Saurischia in the Jura and Cretaceous Formation, principally in Europe. Revista del Museo do la Plata, Third Series, 29, 35-167.

Hulke, J.W. 1879. Note on Poikilopleuron bucklandi of EudesDeslongchamps (pere) identifying it with Megalosaurus bucklandi. Quarterly Journal of the Geological Society of London, 35, 233-238.

Hutt, S., Naish, D., Martill, D.M., Barker, M.J. \& Newbery, P. 2001. A preliminary account of a new tyrannosauroid theropod from the Wessex Formation (Early Cretaceous) of southern England. Cretaceous Research, 22, 227-242.

Insole, A.N. \& Hutt, S. 1994. The palaeoecology of the dinosaurs of the Wessex Formation (Wealden Group, Early Cretaceous), Isle of Wight, Southern England. Zoological Journal of the Linnean Society, 112, 197-215.

International Commission on Zoological Nomenclature. 1999. International Code of Zoological Nomenclature (4th). International Trust for Zoological Nomenclature, London.

Jurcsák, T. 1982. Occurrences nouvelles des sauriens mesozoiques de Roumania. Vertebrata Hungarica, 21, $175-184$.

Jurcsák, T. \& Popa, E. 1983. La fauna de dinosauriens du Bihor (Roumanie). In (Buffetaut, E., Mazin, J.-M. \& Salmon, E.; eds) Actes du Symposium Paleontologique G. Cuvier, Montbeliard. Ville de Montbeliard, 325-335.

Kerth, M. \& Hailwood, E.A. 1988. Magnetostratigraphy of the Lower Cretaceous Vectis Formation (Wealden Group) of the Isle of Wight, southern England. Journal of the Geological Society, London, 145, 351-360.

Kirkland, J.I., Britt, B.B., Whittle, C.H., Madsen, S.K. \& Burge, D.L. 1998. A small coelurosaurian theropod from the Yellow Cat Member of the Cedar Mountain Formation (Lower Cretaceous, Barremian) of eastern Utah. New Mexico Museum of Natural History and Science Bulletin, 14, 239-248.

Kurochkin, E.N. 1995. Synopsis of Mesozoic birds and early evolution of Class Aves. Archaeopteryx, 13, 47-66.

Lydekker, R. 1888. Catalogue of the Fossil Reptilia and Amphibia in the British Museum (Natural History) Part I Containing the orders Ornithosauria, Crocodilia, Dinosauria, Squamata, Rhynchocephalia and Proterosauria. British Museum (Natural History), London.

Lydekker, R. 1889. On a coeluroid dinosaur from the Wealden. Geological Magazine, 6, 119-121.

Lydekker, R. 1891. On certain ornithosaurian and dinosaurian remains. Quarterly Journal of the Geological Society of London, 47, 41-44.
Madsen, J. 1974. A new theropod dinosaur from the Upper Jurassic of Utah. Journal of Paleontology, 48, 27-31.

Mantell, G.A. 1846. On the fossil remains of birds in the Wealden strata of the south-east of England. Quarterly Journal of the Geological Society, 2, 104-106.

Marsh, O.C. 1884a. Principal characters of American Jurassic dinosaurs. Pt. VIII. The order Theropoda. American Journal of Science (ser. 3), 27, 329-340.

Marsh, O.C. 1884b. The principal characters of American Jurassic dinosaurs belonging to the Order Theropoda. The Geological Magazine, 1, 252-262.

Martill, D.M. \& Naish, D. 2001. Dinosaurs of the Isle of Wight. Palaeontological Association, London.

Martill, D.M., Frey, E., Sues, H.-D. \& Cruickshank, A.R.I. 2000. Skeletal remains of a small theropod dinosaur with associated soft structures from the Lower Cretaceous Santana Formation of northeastern Brazil. Canadian Journal of Earth Sciences, 37, 891-900.

Molnar, R.E. 1992. Problematic Theropoda: 'Carnosaurs'. In (Weishampel, D.B., Dodson, P. \& Osmolska, H.; eds) The Dinosauria. University of California Press, Berkeley, 306-317.

Naish, D. 1999a. Studies on Wealden Group theropods - an investigation into the historical taxonomy and phylogenetic affinities of new and previously neglected specimens. MPhil thesis, University of Portsmouth.

Naish, D. 1999b. Theropod dinosaur diversity and palaeobiology in the Wealden Group (Early Cretaceous) of England: evidence from a previously undescribed tibia. Geologie en Mijnbouw, 78, 367-373.

Naish, D. 1999c. Fox, Owen and the small Wealden theropods Calamospondylus and Aristosuchus. Journal of Vertebrate Paleontology, 19 (Suppl. 3), 66.

Naish, D. 2000a. A small, unusual theropod (Dinosauria) femur from the Wealden Group (Lower Cretaceous) of the Isle of Wight, England. Neues Jahrbuch für Geologie und Paläontologie Monatshefte, 2000, 217-234.

Naish, D. 2000b. Theropod dinosaurs in the trees: a historical review of arboreal habits amongst nonavian theropods. Archaeopteryx, 18, 35-41.

Naish, D. \& Martill, D.M. 2002. A reappraisal of Thecocoelurus daviesi (Dinosauria: Theropoda) from the Early cretaceous of the Isle of Wight. Proceedings of the Geologists' Association, 113, 23-30

Naish, D., Hutt, S. \& Martill, D.M. 2001. Saurischian dinosaurs 2: Theropods. In (Martill, D.M. \& Naish, D.; eds) Dinosaurs of the Isle of Wight. Palaeontological Association, London, 242-309.

Norell, M.A. \& Makovicky, P.J. 1997. Important features of the dromaeosaur skeleton: information from a new specimen. American Museum Novitates, 3215, 1-28.

Norman, D.B. 1985. The Illustrated Encyclopedia of Dinosaurs. Salamander, London.

Norman, D.B. 1990. Problematic Theropoda: 'Coelurosauria'. In (Weishampel, D.B., Dodson, P. \& Osmolska, H.; eds) The Dinosauria. University of California Press, Berkeley, 280-305.

Olshevsky, G. 1991. A Revision of the Parainfraclass Archosauria Cope, 1869, Excluding the Advanced Crocodylia. Publications Requiring Research, San Diego.

Ostrom, J.H. 1970. Stratigraphy and paleontology of the Cloverly Formation (Lower Cretaceous) of the Bighorn Basin area, Wyoming and Montana. Peabody Museum of Natural History Bulletin, 35, 1-234.

Ostrom, J.H. 1978. The osteology of Compsognathus longipes Wagner. Zitteliana, 4, 73-118. 
Owen, R. 1842. Report on British fossil reptiles. Report of the British Association for the Advancement of Science, 11, 60-204.

Owen, R. 1855. Monograph on the fossil Reptilia of the Wealden and Purbeck Formations. Part II. Dinosauria. Palaeontographical Society Monograph 14, (Part II), $1-54$.

Owen, R. 1857. Monograph on the Fossil Reptilia of the Wealden and Purbeck Formations. Part III. Dinosauria (Megalosaurus). (Wealden). Palaeontographical Society Monograph, 14 (Part III), 1-26.

Owen, R. 1876. Monograph of the fossil Reptilia of the Wealden and Purbeck Formations. Supplement 7. Crocodilia (Poikilopleuron), Dinosauria (Chondrosteosaurus). Palaeontographical Society Monograph, 30 (Suppl. 7), 1-7.

Paul, G.S. 1988. Predatory Dinosaurs of the World. Simon and Schuster, New York.

Rauhut, O.W.M. \& Werner, C. 1995. First record of the family Dromaeosauridae (Dinosauria: Theropoda) in the Cretaceous of Gondwana (Wadi Milk Formation, northern Sudan). Paläontologische Zeitschrift, 69, 475-489.

Seeley, H.G. 1882. On Thecospondylus horneri, a new dinosaur from the Hastings Sand, indicated by the sacrum and the neural canal of the sacral region. Quarterly Journal of the Geological Society, 38, 457-460.

Seeley, H.G. 1887a. On a sacrum apparently indicating a new type of bird, Ornithodesmus cluniculus Seeley from the Wealden of Brook. Quarterly Journal of the Geological Society of London, 43, 206-211.

Seeley, H.G. 1887b. On Aristosuchus pusillus Ow., being further notes on the fossils described by Sir R. Owen as Poikilopleuron pusillus, Ow. Geological Magazine, 47, 234-235.
Seeley, H.G. 1887c. On Aristosuchus pusillus (Owen), being further notes on the fossils described by Sir R. Owen as Poikilopleuron pusillus Owen. Quarterly Journal of the Geological Society of London, 43, 221-228.

Seeley, H.G. 1888. On Thecospondylus daviesi (Seeley), with some remarks on the classification of the Dinosauria. Quarterly Journal of the Geological Society of London, 44, 79-86.

Steel, R. 1970. Encyclopedia of Paleoherpetology, Part 14: Saurischia. Gustav Fischer Verlag, Stuttgart.

Swinton, W.E. 1936. The dinosaurs of the Isle of Wight. Proceedings of the Geologists' Association, 47, 204-220.

Weishampel, D.B. 1990. Dinosaurian distribution. In (Weishampel, D.B., Dodson, P. \& Osmolska, H.; eds) The Dinosauria. University of California Press, Berkeley, 63-139.

Wellnhofer, P. 1991. The Illustrated Encyclopedia of Pterosaurs. Salamander, London.

$\mathrm{Xu}$, Xing, Wang, Xiao-Lin \& Wu, Xiao-Chun 1999. A dromaeosaurid dinosaur with a filamentous integument from the Yixian Formation of China. Nature, 401, $262-266$

Xu, Xing, Zhou, Zhonghe \& Wang, Xiaolin 2000. The smallest known non-avian theropod dinosaur. Nature, $\mathbf{4 0 8}$, 705-708.

Zhou, Zhong-He \& Wang, Xiao-Lin 2000. A new species of Caudipteryx from the Yixian Formation of Laioning, northeast China. Vertebrata PalAsiatica, 38, 111-127.

Zhou, Zhong-He, Jin, Fan \& Zhang, Jiang-Yong 1992.

Preliminary report on a Mesozoic bird from Liaoning, China. Chinese Science Bulletin, 37, 1365-1368.

Manuscript received 1 January 2001; revised typescript accepted 21 November 2001 